\title{
Service Quality and Customer Satisfaction among Beauty Salons
}

\author{
Rey Avila Mangarin ${ }^{1}$, Jennifer C. Gonzaga ${ }^{2}$ \\ ${ }^{I}$ The University of Mindanao (Panabo) \\ ${ }^{2}$ Dean of Business Education, Samal Island City College
}

\begin{abstract}
This study was conducted to determine the significant influence of service quality on customer satisfaction among beauty salons in a certain municipality of Davao del Norte, Philippines. A quantitative non-experimental descriptive-correlational design was employed in the study utilizing a convenient sampling technique among respondents distributed from six beauty salons each with a quota of 50 customers to rate for year 2019. Mean was used to measure the level of service quality and customer satisfaction while linear regression analysis was used in determining what domain of service quality significantly influence customer satisfaction among beauty salons. As a result, service quality was in high level which while customer satisfaction was in moderate level. It was also found out that there is a low positive significant relationship between service quality and customer satisfaction among beauty salons and that $9.06 \%$ of the customer satisfaction can be attributed to service quality. Further, only tangibles domain significantly influences customer satisfaction while the rest did not. Thus, service quality is recommended to be enhanced to achieve a high level of customer satisfaction.
\end{abstract}

Keywords: beauty salons, customer satisfaction, service quality

\section{I.INTRODUCTION}

$\mathrm{E}$ very morning, most people have different rituals of beautifying personally. It involves the daily shower and shave, the weekly nail trim and the monthly haircut. Beauty salon is an establishment that can provide and offer services for both men and women in enhancing their physical image. It offers various services like haircut, hair treatment, foot care and spa, manicure, pedicure etc. However, not all beauty salon can easily gain customers and increase profit due to the lack of information that should from their target individuals (Sena, 2014).

Thousands of beauty care service providers have arrived all over the country in the last decade. The beauty salon industry started to enter the business world hence, customer satisfaction is affected. In order to comprehend the booming industry, understanding the perceptions of the consumers is essential to maintain its quality of giving service (Akter, 2008).

In the Philippines, some beauty salon owners had a problem with the satisfaction of customers. The 'Shawie Beauty Salon' in Lipa City is a famous beauty parlour because of its ambiance and affordable price. Even so, their consumers were not satisfied of the quality of service they offer (e.g., straightening the new colored hair aftermaths hair damage).
The satisfaction of customers towards the type of equality of service will be one of the ways to know the number of target individuals who will patronage the establishment (Kotler, 2009).

This research provides a significant contribution to the quality of service and satisfaction of customers in the beauty salons of a certain municipality in the province of Davao del Norte. The findings of this study would be significant and helpful for salons in deriving a better understanding of giving a quality of service that may positively or negatively influence customer satisfaction towards their business. In addition, the research study would also be beneficial to the business owners as this serve as their guide to enhance their knowledge that can improve and ultimately gain profitability as it may lead to higher customer satisfaction. It is also beneficial to all of the students as they will be informed that there are factors to be considered in studying. Nevertheless, to the future researchers as the findings of the study will serve as their basis and reference for further studies.

\section{Research Objectives}

The main purpose of this study was to determine the significant relationship between the service quality and customer satisfaction in Panabo City. Specifically, this sought:

1. To determine the level of the service quality of beauty salon in a certain municipality of Davao del Norte in terms of:
1.1 tangibles,
1.2 reliability,
1.3 responsiveness,
1.4 assurance, and
1.5 empathy.

2. To determine the level of the customer satisfaction of beauty salons in a certain municipality of Davao del Norte in terms of:
2.1 attitude;
2.2 behavior; and
2.3 professional knowledge and skills

3. To determine the significant relationship between the service quality and customer satisfaction among beauty salons in a certain municipality of Davao del Norte. 
4. To determine the significant influence of service quality to customer satisfaction among beauty salons in a certain municipality of Davao del Norte.

5. To determine what domain in the service quality significantly influence customer satisfaction among beauty salons in a certain municipality of Davao del Norte.

\section{Hypothesis}

The following hypotheses were tested at 0.05 level of significance:

1. To determine the significant relationship between the service quality and customer satisfaction among beauty salons in a certain municipality of Davao del Norte.

2. To determine the significant influence of service quality to customer satisfaction among beauty salons in a certain municipality of Davao del Norte.

3. To determine what domain in the service quality significantly influence customer satisfaction among beauty salons in a certain municipality of Davao del Norte.

\section{THEORETICAL FRAMEWORK}

This study is anchored on the concept of Khan and Tabassum (2010) that the intensifying effect of extra beauty conscious in globalization made the beauty salons as one of the flourishing industries. Like any other service provider industries, service is the best source of profitability inside the beauty parlors. That is why an initiative is made through questionnaires that became the basis of getting the findings of the study. It was discussed that customer gave significance to the beauty parlors that has a good ambiance of environment, better facilities, information-dissemination desks, prices offers and the employees behaviour and learning when delivering a service. Most importantly, it was emphasized that when measuring the service quality and customer satisfaction of the customers, SERVQUAL model was used. In this case, 10 dimensions were considered which are tangibility, reliability, responsiveness, competence, courtesy, credibility, feel secure, access, communication and understanding the customers and measured through different criteria.

Also, the proposition of Azad (2015) is another basis of this study that customer satisfaction is one of the ways in identifying customers positive feeling and behaviour toward an establishment. The findings of the study revealed five factors and each factor has an important influence to beauty parlors in improving the service. Profits and gains of the company should not only be the center of attraction but the assurance, reliability, tangibility, empathy and responsiveness since it is fairly important in dealing customer's satisfaction.

This is also supported by Panicker and Muhammad (2017) that beauticians/hairdresser at the parlor has great contribution in gathering satisfaction of customers. Also, a great service quality results in excellent customer satisfaction which in return, the loyalty of the customers. Most of women are very accurate regarding the behaviour of the employees serving them. Once they're satisfied with one particular employee, they would prefer the same employee in receiving the service once they visit again the said beauty parlor. Through this study, findings concluded that service quality provided by the employees and customer satisfaction associated with great performance has a strong relationship.

\section{Conceptual Framework}

\section{Independent Variable Dependent Variable}

\begin{tabular}{|ll|l|l|}
\hline \multicolumn{2}{|c|}{ Service Quality } & \multicolumn{1}{|l}{ Customer Satisfaction } \\
1. & Tangibles & \\
2. & Reliability & Attitude \\
3. & Responsiveness & 2. Behaviour \\
4. & Assurance & Empathy & Professional \\
5. & knowledge and Skills \\
\hline
\end{tabular}

Figure 1: The Conceptual Framework of the Study

The figure shows the relationship of Service Quality and Customer Satisfaction. The independent variable is service quality which according to Gronroos (2005) has the following indicators: tangibles or the physical facilities which refers to the equipment and materials used by the employees in the establishment; reliability refers to the provision of service accurately and reliable in delivering the benefit; responsiveness refers to the willingness of the employees to respond and serve promptly to customers' request; assurance refers to the employees' knowledge and behaviour; and empathy refers to the trust and confidence to receive the labour and the ability of the employees in the establishment and the competence in offering the service on its given operating time.

While the dependent variable is customer satisfaction which according to Chen (2008) has the following indicators: attitude refers to the manifestation of how the customers respond to the service and goods provided; behaviour refers to the manifestation of the characters of the customers with regards to the service and products; and the professional skills and knowledge refers to the manifestation of customers of satisfaction to the knowledge and skills manifested by the employees.

\section{Research Design}

This study used a quantitative non-experimental correlational design. This method was used in those cases when there is an interest to identify the existence, strength and direction of relationships between two variables (Holton and Burnett, 2005). In this study, it is used to determine service quality and satisfaction of among beauty salons through survey questionnaires and appropriate statistical treatment.

\section{Research Locale}

The figure shows the map of the Davao del Norte highlighting the municipality of Sto. Tomas, officially the Municipality of 
Santo Tomas (Cebuano: Lungsod sa Santo Tomas; Tagalog: Bayan ng Santo Tomas), is a $1 \mathrm{st}$ class municipality in the province of Davao del Norte, Philippines. According to the 2015 census, it has a population of 118,750 people. Significant to the economic development of Santo Tomas is a number of multi-national corporations and cooperatives engaged in banana based commercial production successfully operating in the municipality. Rice production also contributes to the economic development of the municipality. SantoTomas was part of the lists for the top 15 richest municipality in Davao Region which was listed as the second place.

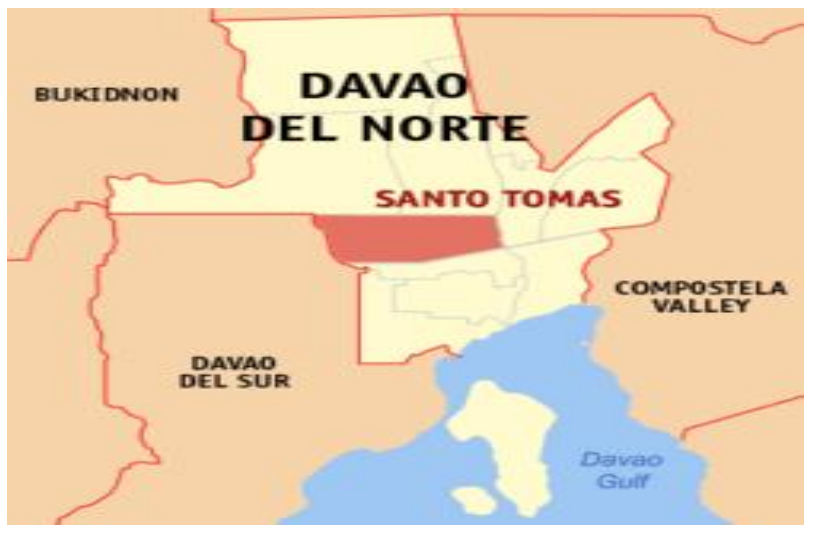

Figure 2: Map of Davao del Norte Highlighting Sto.Tomas, Davao del Norte

\section{Population and Sample}

Respondents of the study were 300 customers from six beauty salons in a certain municipality of Davao del Norte from January 2019 to May 2019. The survey questionnaires were rated by random customers who availed the service of the salons. The researchers left the questionnaires and let the management answered them to their customers. 50 repsondents each salon was allotted which is based on the proposition of Agbor and Eriksson (2011) who proposed that in order to saturate the data for a better results, customers expectation and satisfaction towards a beauty care service which they used a descriptive research and mainly primary data from 50 respondents through questionnaire. By analyzing the data using statistical tools, certain recommendations and suggestions were given to improve the profit of the establishment.

Table 1: Distribution of the Respondents

\begin{tabular}{|c|c|}
\hline Respondents & Number of Respondents \\
\hline Beauty Salon 1 & 50 \\
\hline Beauty Salon 2 & 50 \\
\hline Beauty Salon 3 & 50 \\
\hline Beauty Salon 4 & 50 \\
\hline Beauty Salon 5 & 50 \\
\hline Beauty Salon 6 & 50 \\
\hline
\end{tabular}

\section{Research Instrument}

The study used two sets of survey questionnaires to gather data for quality service and customer satisfaction among beauty salons. The first questionnaire has 25 items, five items each indictor. The questionnaire was pilot tested gaining a reliability index of 0.78 while the customer satisfaction questionnaire with 15 items distributed to three indicators with five items each has reliability index $t$ of 0.81 .

The following scales were used to determine the service quality:

\begin{tabular}{|c|c|c|}
\hline Scale & $\begin{array}{c}\text { Descriptive } \\
\text { Equivalent }\end{array}$ & Interpretation \\
\hline $4.21-5.00$ & Very High & $\begin{array}{c}\text { This means that the quality } \\
\text { of service is outstanding. }\end{array}$ \\
\hline $3.41-4.20$ & High & $\begin{array}{c}\text { This means that the quality } \\
\text { of service is outstanding. }\end{array}$ \\
\hline $2.61-3.40$ & Moderate & $\begin{array}{c}\text { This means that the quality } \\
\text { of service is satisfactory. }\end{array}$ \\
\hline
\end{tabular}

\begin{tabular}{|c|c|c|}
\hline Scale & $\begin{array}{c}\text { Descriptive } \\
\text { Equivalent }\end{array}$ & Interpretation \\
\hline $4.21-5.00$ & Very High & $\begin{array}{c}\text { This means that the } \\
\text { quality of service is } \\
\text { outstanding. }\end{array}$ \\
\hline $3.41-4.20$ & High & $\begin{array}{c}\text { This means that the } \\
\text { quality of service is } \\
\text { very satisfactory. }\end{array}$ \\
\hline $2.61-3.40$ & Moderate & $\begin{array}{c}\text { This means that the } \\
\text { quality of service is } \\
\text { satisfactory. }\end{array}$ \\
\hline $1.81-2.60$ & Low & $\begin{array}{c}\text { This means that the } \\
\text { quality of service is } \\
\text { poor. }\end{array}$ \\
\hline $1.00-1.80$ & Very Low & $\begin{array}{c}\text { This means that the } \\
\text { poor. }\end{array}$ \\
\hline $1.00-1.80$ & Very Low & $\begin{array}{c}\text { This means that the } \\
\text { quality of service is } \\
\text { very poor. }\end{array}$ \\
\hline
\end{tabular}

The following scales were used to determine the customer satisfaction.

\begin{tabular}{|c|c|c|}
\hline Scale & $\begin{array}{c}\text { Descriptive } \\
\text { Equivalent }\end{array}$ & Interpretation \\
\hline $4.21-5.00$ & Very High & $\begin{array}{r}\text { This means that the satisfaction of } \\
\text { customers is outstanding. }\end{array}$ \\
\hline $3.41-4.20$ & High & $\begin{array}{c}\text { This means that the satisfaction of } \\
\text { customers is very satisfactory. }\end{array}$ \\
\hline $2.61-3.40$ & Moderate & $\begin{array}{c}\text { This means that the satisfaction of } \\
\text { sustomers is }\end{array}$ \\
\hline $1.81-2.60$ & Low & $\begin{array}{c}\text { This means that the satisfaction of } \\
\text { customers is poor. }\end{array}$ \\
\hline $1.00-1.80$ & Very Low & $\begin{array}{r}\text { This means that the satisfaction of } \\
\text { customers is very poor. }\end{array}$ \\
\hline
\end{tabular}

\section{Data Collection}

In collecting data, the researchers first took permission to conduct the survey question and a letter was sent to the owner and management of the establishment. After the researchers gained the permission from the owner, they started collecting the data by leaving to the management the survey questionnaires for them allow their customers respond to the 
survey. Then retrieving all the questionnaires after all the respondents have answered the questionnaires was taken after the management communicated the researchers that all questionnaires were done rated. And lastly, the researchers checked, tabulated, and statistically processed the data that they collected.

\section{Statistical Tools}

The following statistical tools were used to analyse the data:

Weighted mean: This was used to determine the level of service quality in term of tangibles, reliability, responsiveness, assurance and empathy. This was also used to determine the level of customer satisfaction in terms of attitude, behavior and professional knowledge and skills.

Pearson-r: This was used to determine the significant relationship between the quality of service and satisfaction of customer.

Regression Analysis: This was used to determine which domain in the quality service significantly influence customer satisfaction.

\section{RESULTS AND DISCUSSION}

The following were the results of this study:

\section{The Level of Quality Service}

Of all five indicators, two are in high level which are tangibles $(x=4.11 ;$ S.D. $=0.54)$ and assurance $(x=4.00 ;$ S.D. $=0.57)$; while reliability is in very high level $(x=4.21 ; \quad S . D .=0.56)$; responsiveness is in moderate level $(x=3.34 ;$ S.D. $=0.40)$, and empathy is in low level $(x=2.41 ; S . D .=0.70)$. These results lead to a high level of quality service $(x=3.60 ;$ S.D. $=0.37)$.

Table 2: The Level of Quality Service among Beauty Salons

\begin{tabular}{|l|c|c|c|}
\hline \multicolumn{1}{|c|}{ Indicator } & Mean & \multicolumn{1}{c|}{ S.D. } & $\begin{array}{c}\text { Descriptive } \\
\text { Equivalent }\end{array}$ \\
\hline Tangibles & 4.1087 & 0.54404 & High \\
\hline Reliability & 4.2107 & 0.56012 & Very High \\
\hline Responsiveness & 3.3404 & 0.40288 & Moderate \\
\hline Assurance & 4.0027 & 0.57413 & High \\
\hline Empathy & 2.4133 & 0.69758 & Low \\
\hline Over-all Mean & 3.5959 & 0.36698 & High \\
\hline
\end{tabular}

\section{The Level of Customer Satisfaction}

The three indicators of customer satisfaction were all in different levels. Attitude is moderate level $(x=2.98$; S.D. $=0.54)$; behavior is in low level $(x=2.48 ;$ S.D. $=0.92)$; and professional knowledge and skills is in high level $(x=3.48$; S.D. $=0.65)$. These results lead to a moderate level of customer satisfaction $(x=3.60 ;$ S.D. $=0.37)$.

Table 3: The Level of Customer Satisfaction among Beauty Salons

\begin{tabular}{|c|c|c|c|}
\hline Indicator & Mean & S.D. & $\begin{array}{c}\text { Descriptive } \\
\text { Equivalent }\end{array}$ \\
\hline Attitude & 2.98 & 0.54 & \\
\hline Behavior & 2.48 & 0.92 & \\
\hline Professional & 3.48 & 0.65 & \\
\hline
\end{tabular}

\begin{tabular}{|c|l|l|l|}
\hline $\begin{array}{c}\text { Knowledge and } \\
\text { Skills }\end{array}$ & & & \\
\hline Over-all Mean & 2.98 & 0.52 & \\
\hline
\end{tabular}

The Significant Relationship between Quality Service and Customer Satisfaction

As shown in the table above, quality service has a significant low positive correlation $(r$-value $=0.301 ; p<0.000)$ to customer satisfaction based from the rejection of the hypothesis at 0.05 level of significance. Moreover, only $9.06 \%$ of the customer satisfaction can be attributed to quality service.

Table 4: The Significant Relationship Between Quality Service and Customer Satisfaction among Beauty Salons

\begin{tabular}{|l|c|c|c|}
\hline \multicolumn{1}{|c|}{ Variable } & r-value & p-value & Decision \\
\cline { 1 - 1 } Quality Service & 0.301 & 0.000 & $\begin{array}{c}\text { Reject the } \\
\text { Hypothesis }\end{array}$ \\
\cline { 1 - 2 } Customer Satisfaction & & & \\
\hline
\end{tabular}

$\alpha=0.05$

The Significant Influence of Quality Service to Customer Satisfaction

As shown in the above table, only tangibles indicator significantly influence $(p$-value $<0.05)$ customer satisfaction. The rest of the indicators of quality service, to wit, reliability, responsiveness, assurance, and empathy have no significant influence ( $p$-value $>0.05$ ) to quality service.

As can be seen, quality service has significant influence to quality service. The regression model produced $\mathrm{R}^{2}=0.145$, $\mathrm{F}=10.007, \mathrm{p}<0.05$. This is in rejection of the hypothesis that quality service does not significantly influence creating healthy organizations. Moreover, only $9.06 \%$ of the customer satisfaction can be attributed to quality service.

Thus, the following working model is generated based on the statistical results:

$$
\text { Customer Satisfaction }=1.626+0.134 * \text { Tangibles }
$$

Table 5: The Significant Influence of Quality Service to Customer Satisfaction among Beauty Salons.

\begin{tabular}{|c|c|c|c|c|}
\hline \multirow[t]{2}{*}{ Indicator } & \multicolumn{2}{|c|}{$\begin{array}{c}\text { Multiple } \\
\text { Regression Weight }\end{array}$} & \multirow{2}{*}{$\begin{array}{c}\text { t-valu } \\
\mathrm{e}\end{array}$} & \multirow[b]{2}{*}{ p-value } \\
\hline & $\mathrm{b}$ & $\beta$ & & \\
\hline Constant & 1.626 & & 5.548 & .000 \\
\hline Tangibles & .134 & .139 & 2.253 & .025 \\
\hline Reliability & -.018 & -.019 & -.243 & .809 \\
\hline Responsiveness & .177 & .136 & 1.682 & .094 \\
\hline Assurance & -.055 & -.060 & -1.039 & .300 \\
\hline Empathy & .210 & .281 & 4.774 & .000 \\
\hline Quality Service & & & & 0.000 \\
\hline
\end{tabular}

$\alpha=0.05$

\section{DISCUSSION}

The physical facilities like the equipment and materials used by the salons is very satisfactory. The provision of service by the beauty salons accurately and reliable in delivering the benefit was outstanding. While there was a satisfactory responsiveness 
like willingness of the beauty salon employees to respond and serve promptly to customers' request. Also, a very satisfactory employees' knowledge and behavior in providing the service is manifested. While the trust and confidence to receive the labor and the ability of the employees in the establishment and the competence in offering the service on its given operating time is poor.

This study of by Khan and Tabassum (2010) supported through their argument that all the criteria in the findings got above average scores, which means the service performance on those criteria was more or less satisfactory to the customer.

In addition, as manifested in the results, there was a satisfactory manifestation of how the customers respond to the service and goods provided. However, there was a poor manifestation of the characters of the customers with regards to the service and products. Lastly, a very satisfactory feedback on the professional skills and knowledge of the employees was found.

The study of Sobolewska, Michalski, and Kierasinska (2015) can be used as supporting knowledge of the above that the satisfaction feelings is an important factor in the process of acquisition and retention of customers. Investigation and monitoring of the level of their satisfaction become essential process of marketing research carried out by companies operating in almost all sectors of the economy. It is pointing out the shortcomings, weaknesses offered goods, services or their quality. Compliance of consumers' expectations and demands, recognition of their unconscious needs, is not currently a priority, but it is standard.

Further, quality service has a significant low positive correlation to customer satisfaction. Moreover, only $9.06 \%$ of the customer satisfaction can be attributed to quality service.

This result is supported by Nakashima, Putro, Mulyono, and Takeshi (2010) that customer's perception of service quality can be drawn from those relationships. It was indicated how the quality of services is perceived differently by customers who have different value and life style, and also describe significant relationship between value and life style with the affecting factors of service quality.

Only tangibles indicator significantly influence customer satisfaction. The rest of the indicators of quality service, to wit, reliability, responsiveness, assurance, and empathy have no significant influence to quality service.

The working model is Customer Satisfaction $=1.626+$ $0.134 *$ Tangibles.

The study of Park (2007) supports that the effects on customer satisfaction was significantly affected by facilities of hair beauty salon, employee`s kindness, guidance to a process of hair style, customer management, keeping service for personal belongings, light refreshments. Moreover, it can be noted also that customer satisfaction with hair beauty service affected the word-of-mouth intention.

\section{CONCLUSION}

Tangibles and assurance are in high level. While reliability is in very high level. Responsiveness is in moderate level. Empathy is in low level. Service quality is in high level.

Attitude is in moderate level, behavior is in low level, and professional knowledge and skills is in high level. The level of customer satisfaction is moderate.

Quality service has a significant low positive correlation to customer satisfaction. Moreover, only $9.06 \%$ of the customer satisfaction can be attributed to quality service.

Only tangibles indicator significantly influence customer satisfaction. The rest of the indicators of quality service, to wit, reliability, responsiveness, assurance, and empathy have no significant influence to quality service.

The working model is Customer Satisfaction $=1.626+$ $0.134 *$ Tangibles.

\section{RECOMMENDATION}

Salon owners and management are recommended to take initiatives in enhancing tangibles, assurance, responsiveness, and empathy dimensions. Service quality is highly recommended to be enhanced. Also, the attitude, behavior, and professional knowledge and skills are recommended to enhance. The level of customer satisfaction is recommended to be enhanced also.

Employees who directly provide services in the beauty salons are recommended to work collaboratively with the management to enhance the dimensions mentioned above.

The working model is Customer Satisfaction $=1.626+$ $0.134 *$ Tangibles is recommended to be used as basis to how the physical features of the salon can be improved to meet the desired level of satisfaction from the customers.

Further research studies exploring other dimensions of service quality that significantly influential factor to customer satisfaction and as well as other approaches are recommended to be conducted. Moreover, other variables that affect customer satisfaction are also recommended to be tested. Lastly. Same study replicating this idea to other settings is recommended to be conducted.

\section{REFERENCES}

[1] Agbor, J. \& Eriksson, J. (2011). The Relationship between Customer Satisfaction and Service Quality: a study of three Service sectors in Umeå. Retrieved from http://www.diva-portal.org/smash/get/diva2:448657/FULLTEXT0 2.pdf.

[2] Akter, S. (2008). The Business of Beauty. The Daily Star. Retrieved from https://www.thedailystar.net/news-detail-41992

[3] Azad, S. (2015). The Relationship Between Service Quality and Customer Satisfaction in Reference with Bangladesh Beauty Parlors. Retrieved from https://epatrust.com/articles/upload/3.Sumi\%20Azad.pdf?

[4] Chen, T. (2008). The examination of factors that affect the relationship between employee-customer satisfaction in recreational sport/fitness clubs in Taiwan (Order No. 3319541). 
Available from ProQuest Central. (304825690). Retrieved from https://www.search.proquest.com/docview/304825690?accountid= 31259

[5] Grönroos, C. (2005). Service Management and Marketing. A customer relationship management approach. Swedish School of Economics and Business Administration. Retrieved from https://www.researchgate.net/publication/215915793_Service_Ma nagement_and_Marketing_A_Customer_Relationship_Manageme nt_Approach

[6] Holton, E.F.\& Burnett, M. F. (2005). The Basics of Quantitative Research. In R. A. Swanson \& E. F. Holton (Eds.), Research in organizations: Foundations and methods of inquiry. San Francisco. pp 29-44. Retrieved on July 8, 2019 from https://www.bkconnection.com/static/Research_In_Organization_ EXCERPT.pdf

[7] Khan, P.I. and Tabassum, A.(2010). Service Quality and Customer Satisfaction of the Beauty-Care Service Industry in Dhaka: A Study on High-End Women's Parlors; Retrieved from https://www.semanthicscholar.org/paper/Service-Quality-and-Cust omer-Satisfaction-of-the-in-Khan-Tabassum/d06e10cb5c7b21d4c 9c18892f20a3f9ace671b96

[8] Kotler, P. (2009). Marketing management. Publish by: Pearson Edition, Pearson Educational South Firstlok Young Road, Jurong, Singapore 629733 page 23-24. Retrieved from https://www.person.com/us/higher_education_product_Ketler_Ma rketing_Management_15th edition/9780133856460.html
[9] Nakashima, K., Putro, U., Mulyono, N., \& Takeshi, A. (2010). Factors Affecting Customer's Perception of Service Quality: Comparing Differences among Countries. Retrieved from https://media.neliti.com/media/publications/56959-EN-factors-affe cting-customers-perception-o.pdf.

[10] Park, E. (2007). The Effects of Beauty Service on Customer Satisfaction and Word-of-Mouth Intention in the Beauty Industry. Retrieved from https://www.researchgate.net/publication/276219111_The_Effects _of_Beauty_Service_on_Customer_Satisfaction_and_Word-of-M outh_Intention_in_the_Beauty_Industry.

[11] Panicker, V. B. and Mohammad K, A. (2017). A Study on the Service Quality Attributes of Parlour Service Employees and Their Contribution to Customer Satisfaction in the Beauty Care Service Industry. Retrieved from https://www.ijbmi.org/papers/Vol(6)11/Version-2/D0611022228.p df

[12] Sena, M. (2014). Beauty industry analysis 2014 - Cost \& Trends Franchise help. 2014. Retrieved from https://www.franchisehelp.com/industryreports/beauty-industry-re port/.

[13] Sobolewska, E., Michalski, J., \& Kierasinska, H. (2015). Customer satisfaction of beauty salon and SPA resources part I. Retrieved from https://www.researchgate.net/publication/275349898_Customer_s atisfaction_of_beauty_salon_and_SPA_resources_part_I. 